\title{
Paideusis
}

\section{The Good Life of Teaching: An Ethics of Professional Practice (Chris Higgins)}

\section{Clarence W. Joldersma}

Volume 21, Number 1, 2013

Contemplative Practice, Education, and Socio-Political

Transformation (Part Two)

URI: https://id.erudit.org/iderudit/1071576ar

DOI: https://doi.org/10.7202/1071576ar

See table of contents

Publisher(s)

Canadian Philosophy of Education Society

ISSN

0838-4517 (print)

1916-0348 (digital)

Explore this journal

Cite this review

Joldersma, C. (2013). Review of [The Good Life of Teaching: An Ethics of

Professional Practice (Chris Higgins)]. Paideusis, 21(1), 54-56.

https://doi.org/10.7202/1071576ar

This document is protected by copyright law. Use of the services of Erudit (including reproduction) is subject to its terms and conditions, which can be viewed online.

https://apropos.erudit.org/en/users/policy-on-use/ 
Paideusis, Volume 22 (2013), No. 1, pp. 54-56.

Review of

\title{
The Good Life of Teaching: An ethics of professional practice
}

\author{
by Chris Higgins, Oxford: Wiley-Blackwell, 2011. Price: \$39,95 (pb). ISBN-13: 978-
}

1444339307

\author{
CLARENCE W. JOLDERSMA \\ Calvin College, Grand Rapids, MI
}

Los Angeles super-teacher Rafe Esquith has been held up as a model for excellent teaching, winning Disney's National Outstanding Teacher of the Year Award and Parents Magazine's As You Grow Award. Not content with the progress of his inner-city students, and working on the premise that "there are no shortcuts" (the title of the book he wrote about his teaching), he asked them to be at school at 6:30 rather than the regular 8:00 am, and not leave before 6:00 pm, rather the regular 3:00 o'clock. In addition, he organized and supervised students coming in on Saturdays during the school year and also in the summers, when he taught them enrichment and remedial classes. He also took them on camping trips, tours of the mid-west, and trips to Washington DC-raising his own money for the required airfare, textbooks, and musical instruments. Often he worked extra jobs on weekends and nights to raise the cash himself. In short, he is held up as an exemplary teacher precisely because teaching totally engulfed his entire life, including his time for sleeping. Extreme self-sacrifice, it would appear, is what constitutes exemplary teaching in the social imaginary-forfeiting oneself for one's student's success (Rothstein, 2004, p. 81).

When we hold up teachers like Esquith as the ideal, we suppose that the goodness of teaching lies exclusively in the achievements of one's students. This means that we suppose teaching to be the epitome of a helping profession, typically thought of as serving others at the personal cost of denying and neglecting oneself. The excellence of teaching, put in terms of helping, is usually described in selfsacrificial terms. Simultaneously, in the climate of equating student success to their performance on tests of basic skills, the goodness of teaching as helping is indexed to externally-set student proficiencies, usually narrowed to math and reading. Chris Higgins worries about this image of good teaching. He suggests that glaringly missing from this image is teaching's intrinsic goodness as well as the flourishing of teachers themselves. The Good Life of Teaching is an account of how and why teaching is intrinsically rewarding and why teachers have a right if not a duty to care about their own human flourishing.

However, The Good Life of Teaching is not a self-help book of practical tips for harried or burned out practitioners. Instead, it is a book on professional ethics, in which Higgins seeks to reconceptualize the practice of teaching and the self-understanding of teachers. He does so by modeling teaching as "teacherly self-cultivation" (p. 2), central to which is his MacIntyrean idea of teaching as a social practice. He suggests teachers need to replace the question, "why teach" with a longer one, "why is the

(C) Copyright 2013. Clarence Joldersma assigns to Paideusis the right of first publication and educational and non-profit institutions a non-exclusive license to use this document for personal use and in courses of instruction provided that the article is used in full and this copyright statement is reproduced. Any other usage is probibited without the express permission of the author. 
practice of teaching worth putting at the center of one's life?" (p. 9). This, he suggests, gets us into the realm of professional ethics. By ethics he means developing answers to deep and rich questions such as "what does it mean to be fully human" and "what would make my life meaningful, excellent or rich?" (p. 9). These questions get at the good life of teaching, he argues, connecting the activity of teaching with the question of how one should live. Higgins takes the rest of the book to develop what sort of good life is internal to the practice of teaching. He draws on a number of well-known social theorists, including Bernard Williams and Charles Taylor (Chapter 1 \& 5), Alasdair MacIntyre (Chapter 2 \& 6), Hannah Arendt (Chapter 3 \& 7), and John Dewey and Hans-Georg Gadamer (Chapter 4 \& 8). From each he develops a specific piece of the puzzle that he puts together into a composite whole. By the end he builds a convincing case that teaching is a form of the good life.

The book is divided into two parts, each with four chapters. In Part I, "The Virtues of Vocation," he develops a conceptual frame for the professional ethics of teaching. This section can be thought of as foundational, for Higgins uses it to develop a rich, composite framework for the next section. In Chapter 1, Higgins criticizes the idea of professional ethics as delineating the boundaries of professional conduct, and instead makes central the ethical import of the human flourishing of the practitioner. This idea, based in the work of Williams and Taylor, makes essential the importance of self-regard and self-cultivation, thereby setting the stage for the idea that our paid work can contribute to leading the good life. In the next chapter, Higgins rehearses MacIntyre's idea of social practice in order to highlight the idea of a practice's internal goods as a distinctive vision of what is worthwhile. This makes these goods into specific excellences, sources of ethics rather than neutral (and external) goals. Chapter 3 explicates Arendt's distinctions between labor, work and action in order to articulate the possibility of fresh beginnings and the uniqueness of each person in practical life. The final chapter of the section develops the idea of experience in Dewey and Gadamer to highlight the importance of openness to newness as central to practical wisdom.

Part II, "A Virtue Ethics for Teachers," takes the framework of Part I to develop a case for the good life intrinsic to the practice of teaching. Chapter 5 picks up a thread from Chapter 1 by focusing on the need for teacherly self-interest, countering the idea of teaching as purely self-sacrificial and altruistic. The next chapter returns to the ideas of Chapter 2, arguing that teaching is a MacIntyrean social practice, but one complicated and compromised by its setting in schools, because of their institutional context and politically narrowed goals. Chapter 7 picks up the Arendt thread of Chapter 3 by arguing for an understanding of teaching that encompasses all three of her categories of the vita activa (labor, work, action), arguing that teaching affords contact with one's own natality and selfenactment. And the final chapter picks up the Deweyan and Gadameran threads of Chapter 4 by highlighting the idea of teaching as an ongoing conversation with the world that involves asking formative questions, which suggests the centrality of hermeneutics in teaching. Together, the two sections form an elaborate argument about the good life of teaching, one which attempts to counteract the neo-liberal, if not neo-conservative, image of teaching. This image portrays teaching both as a selfsacrificial practice and as reducible to a set of techniques for having students master basic skills.

The book's scholarship is excellent. Higgins' writing is clear and careful. His complex argument is solidly established in the several strands of his conceptual framework of Part I and is smartly developed in Part II through the modifications he generates as he weaves together those strands. Along the way, he provides nuanced, detailed, defensible explications of the central ideas of several important social philosophers. In particular, Higgins provides a very clear yet deeply detailed introduction to MacIntyre's idea of social practice in Chapter 2, followed by an equally understandable and clarifying introduction to Arendt's ideas of labor, work and action in the next chapter. For those who aren't familiar with MacIntyre's or Arendt's work, and even for those of us who are, Higgins' introductions to these thinkers already make the book worth reading. Higgins' own philosophical voice emerges most clearly in the detailed, excellent arguments of Part II, where he works MacIntyre against himself to suggest that teaching is a social practice (MacIntyre explicitly didn't think so) and where he complicates Arendt's distinctions within the vita activa to argue that teaching as a social practice must be understood 
as a combination of labor, work, and action. Although (or more likely because) his arguments are built carefully and clearly, his conclusions take him beyond his interlocutors, and his own voice emerges for how and why teaching ought to be considered a social practice with intrinsic excellence: teaching is a form of the good life. I would suggest that the book's scholarship discloses Higgins' own "distinctive personhood" (p. 205), in which something new is "gradually brought into the world" (p. 233).

So, what about Los Angeles super-teacher Rafe Esquith? On the surface, as noted earlier, Esquith might be held up as the epitome of a responsible teacher. It seems as if the core of his very being is constituted by his responsibility to his students. Further, it would seem that his self-sacrifice seemed necessary to help his students succeed in school. But, as Higgins might suggest, Esquith's selfsacrifice of time and money is a result of economic factors beyond his control-the inadequate investment by society in its inner-city school systems. Ironically, Esquith's self-sacrifice forces us to see how expensive in time and money quality education really is. Further, Higgins would rightly argue, Esquith would not be able to continue along this path for very long, for he would all too quickly burn out as a teacher or live vicariously through his students. Higgins insightfully points out that "the very idea of a helping profession is ideological" (p. 164), a rationalization of basic economic disparities forced on certain vocations, most of which "seem to be coded female" (p. 165). In contrast to this, Higgins' analysis suggests that Esquith needs, in order to be good at his teaching, to care for bimself, precisely as a subject. Higgins argues that care for oneself is central to the social practice of teaching, not only to ward off inevitable teacher burn-out, but also to avoid holding up as exemplary the impossible exploits of super-teachers like Rafe Esquith. Higgins's insight forces us to sharpen the distinction between responsibility to one's students and its seeming cognate, teaching as a helping profession. Higgins's insight suggests that we need to bring into sharper relief the fact that care for oneself is not evil, but part of the responsibility one has for ones students. By distinguishing between self-interest and self-realization, Higgins creates rightful room for the idea that care for self is not only proper but also important for the good life.

Care for oneself can be situated in another theme in Higgins' book, namely, that one's subjectivity arises from intersubjectivity. Higgins argues at one point that "intersubjectivity is actually more fundamental that subjectivity" (p. 168). This means that one's own subjectivity requires a connection to another, something he puts in terms of being recognized by another subject. This might, at minimum, mean that Esquith, despite his self-denial, didn't derive his subjectivity from such sacrifice. Rather, Higgins might suggest, his subjectivity as a teacher was constituted at least partly through being recognized as a successful teacher, particularly by his students (and perhaps also by other constituencies). Without his students' recognition and affirmation, Esquith's own satisfaction in teaching would likely not have emerged.

Although (or again, perhaps because) Higgins is a philosopher of education, his book has clarity and accessibility for educators not in philosophy. Teacher educators in initial certification programs could fruitfully engage with the book's ideas, connecting its insights with preparing future teachers in an age of measurement and testing. The book could well be an important resource for resisting the drumbeat of taking teaching to be mostly technique and the teacher a self-less, compliant bureaucrat. This book deserves to be read widely within the sphere of education. It is a book for times such as these.

\section{References}

Rothstein, R. (2004). Class And Schools: Using Social, Economic, And Educational Reform To Close The Blackwhite Achievement Gap. Economic Policy Institute and Teachers College. 